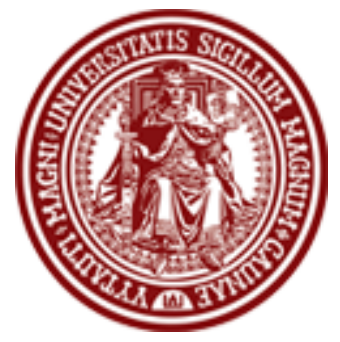

BALTIC JOURNAL OF LAW \& POLITICS

VOLUME 4, NUMBER 1 (2011)

ISSN 2029-0454

http://www.versita.com/bjlp

Cit.: Baltic Journal of Law \& Politics 4:1 (2011): 83-105

DOI: $10.2478 / \mathrm{v} 10076-011-0004-5$

\title{
A CASE STUDY IN THE GLOBALIZATION OF DISABILITY RIGHTS: \\ THE COMPATIBILITY OF LITHUANIA'S PROCESS FOR \\ DETERMINING THE LEGAL INCAPACITY OF DISABLED \\ PERSONS WITH INTERNATIONAL LEGAL STANDARDS
}

\author{
Charles F. Szymanski \\ Professor \\ Vytautas Magnus University Faculty of Law (Lithuania) \\ Adjunct Professor \\ Michigan State University College of Law (USA) \\ Contact information \\ Address: Ozeskienès str. 18, Kaunas 44254, Lithuania \\ Phone: +370-37-751044 \\ E-mail address: c.szymanski@tf.vdu.It
}

\section{Mindaugas Bilius}

M.A.; Doctoral Candidate

Vytautas Magnus University Faculty of Law (Lithuania)

Contact information

Address: Ozeskienès str. 18, Kaunas 44254, Lithuania

Phone: +370-37-751044

E-mail address: m.bilius@tf.vdu.It

Received: April 21, 2011; reviews: 2; accepted: July 15, 2011.

\section{ABSTRACT}

Disability rights law has expanded over the past twenty years from near non-existence to developing into an international legal norm, particularly through the recent United Nations convention on the Rights of Persons with Disabilities. In this work, the authors examine the case of Lithuania and its process for determining when disabled persons lack legal capacity, 
as measured against the international legal standards applicable to this issue. The authors conclude by offering suggestions about how Lithuania may make determinations as to legal capacity in a way that is consistent with the emerging global legal standards on disability rights law.

\section{KEYWORDS}

Disability, legal capacity, mental illness, human rights 


\section{INTRODUCTION}

With its assumption of the chairmanship of the Organization of Security and Cooperation in Europe (OSCE) in $2011^{1}$ and pending presidency of the European Union in $2013^{2}$, Lithuania has achieved a rather outsized profile in European and global affairs as of late. This profile is outsized, of course, only in the sense of the size of Lithuania's population in comparison with the population and economic weight of the organizations it will be leading, and not in comparison to the country's historical and moral contributions to world affairs. Attaining such a status on the world stage brings with it a certain prestige, but at the same time it invites closer scrutiny. While its heroic insistence on preserving its right to independence and freedom in the final years of the Cold War earned it justified international approbation, twenty years have passed since that time and in the public spotlight Lithuania will have its moral leadership reexamined.

An age-old test of the strength of a society's fabric is how it treats the least among its members. In most societies these are its disabled citizens. Over the past twenty years - since the time of the reestablishment of Lithuanian independence the legal rights of disabled persons has grown exponentially throughout the globe. This process culminated most dramatically in the adoption of the Convention on the Rights of Persons with Disabilities (CRPD) in 2006. It has also spawned regional disability rights laws and policies, in Europe most notably the Council of Europe's 10 year action plan for disability rights in Europe (2006-2015) and its earlier 1999 Recommendation on the Legal Protection of Incapable Adults. Lithuania is a member of the Council of Europe, and has signed and ratified the Convention on the Rights of Persons with Disabilities. These developments cannot be praised enough. However, the measure of their current, actual value in Lithuania is whether these new, international disability rights standards are enforced.

Rather than focus on the entire panoply of disability rights, and whether they are applied and enforced in Lithuania, this article will focus on whether one of these rights are being upheld - the right to legal capacity. This is arguably one of the most important rights held by disabled people. Without the status of a legal person, and without the capacity to exercise one's rights, any other rights possessed by the disabled would end up being superfluous.

\footnotetext{
${ }^{1}$ See "Lithuanian Chair of Organization for Security and Cooperation in Europe Sets Out 2011 Priorities as he Briefs Security Council" //

http://www.un.org/News/Press/docs/2011/sc10175.doc.htm (last accessed April 18, 2011).

2 See "Lithuania to Preside over EU" // http://lietuva.It/en/state (last accessed April 18, 2011).
} 
Unfortunately, it appears that Lithuania has fallen short in this test, and that the international standards concerning legal capacity are not being met. Of course, and equally unfortunately, Lithuania is not alone in that regard. However, it is hoped that by highlighting the problem, and suggesting possible solutions, Lithuania will couple its current status of European political leadership with a renewal of its moral leadership, in this case by its treatment of its disabled citizens.

\section{THE PROBLEM OF THE DEPRIVATION OF LEGAL CAPACITY FOR DISABLED PERSONS}

Historically, the state assumed responsibility "to protect the person and property of those individuals whom the State has deemed to be mentally 'incompetent' or 'incapacitated. ${ }^{\prime \prime \prime} 3$ It did so in its capacity as parens patriae, or "parent of the country." ${ }^{4}$ However, such "protection" was not always benign. Instead of focusing on empowering disabled persons to run their own affairs, to the extent possible, the state instead concentrated "on society's desire to protect itself from those deemed 'dangerous' or merely different. Thus, relying on parens patriae, states have used measures such as the adoption of eugenics laws to eliminate the population with severe mental impairments; states have also engaged in the wholesale isolation of individuals in massive state institutions." ${ }^{5}$

Gradually, states shifted from a focus on protecting society from the disabled, to actually taking steps to protect the disabled themselves. This took the form of arranging for guardians to look out for the interests of the disabled, when they could not, in the state's opinion, do so themselves. Before a guardian was appointed, a process was usually held wherein a determination would be made that a disabled person lacked the capacity to look out for his or her own affairs, and otherwise care for his or herself. This process led to the disabled individual being deprived of all or part of his or her legal capacity. ${ }^{6}$

Even ignoring the many instances where this guardianship process was grossly abused, even its regular application had severe consequences for its disabled subjects. Essentially, once a person has been deprived of capacity, and

\footnotetext{
${ }^{3}$ Leslie Salzman, "Rethinking Guardianship (Again): Substituted Decision Making as a Violation of the Integration Mandate of Title II of the Americans with Disabilities Act," 81 U. Colo. L.Rev. 157 (Winter, 2010): 164 .

${ }^{4}$ Ibid.; see also Arlene Kanter, "The United Nations Convention on the Rights of Persons with Disabilities and its Implications for the Rights of Elderly People Under International Law," 25 Ga. St. U. L. Rev. 527 (Spring, 2009): 560.

${ }^{5}$ Ibid. (while the author is describing the practice of the individual states which comprise the United States, this description is equally apt to the "state" at the international level (see ibid.: 560 (making a similar point))).

${ }^{6}$ See ibid.: 560-561; see also Ulrike Buschbacher Connelly, "Disability Rights in Cambodia: Using the Convention on the Rights of People with Disabilities to Expose Human Rights Violations," 18 Pac. Rim L. \& Pol'y J. 123 (January, 2009): 132.
} 
this capacity has in whole or in part has been transferred to a guardian, there is a high risk that the person will simply no longer act. With respect to personal affairs, for example, a person deprived of the right to make financial decisions will likely no longer go to the bank or to shops. Restrictions on independent travel may result in the disabled person not traveling at all. Medical decisions affecting the disabled person may be carried not through (and with the input of) that person, but rather around her between the doctor and the guardian. In all these ways, their loss of capacity separates them further from society: from the bank employees, from their physician, from friends, and most basically from other people. ${ }^{7}$

Moreover, even the label of being "incapable", "incapacitated" or even "incompetent", and having gone through the process of being declared as such, itself has an isolating effect. ${ }^{8}$ Therefore:

Once a person is found to be incompetent, a consequent effect is that a person's own choices and preferences will be ignored and other people will decide for them. This displacement of internal control causes people to believe that the events of their lives are outside their control... the incompetence label forces people to learn helplessness.... Thus people who have been labeled incompetent are deprived of their ability to satisfy the basic human need to be selfdetermining and self-actualizing. ${ }^{9}$

These two factors - the apparent removal of the need to be active, and the psychological effect of helplessness caused by the incapacity label - are mutually self-enforcing. While the state's previous reliance on institutionalization resulted in disabled people being physically isolated from society, it has been suggested that guardianship produces a less severe, but still similar de facto isolating effect. ${ }^{10}$ In the end both are "forms of state sanctioned isolation."11 Beyond isolation, some commentators have gone so far as to call guardianship "civil death". ${ }^{12}$

\footnotetext{
7 See Salzman, supra note 3: 168-169.

${ }^{8}$ Ibid.

${ }^{9}$ Amita Dhanda, "Legal Capacity in the Disability Rights Convention: Stranglehold of the Past or Lodestar of the Future," 34 Syracuse J. Int'l L. \& Com. 429 (Spring 2007): 436-437 (internal quotations omitted); see also Kanter, supra note 4: 561 (noting that a declaration of incompetency may be a "self-fulfilling prophesy").

${ }^{10}$ See Salzman, supra note 3: 170-171.

${ }^{11}$ Ibid. : 171.

12 See Kanter, supra note 4: 561; see also Anna Lawson, "The United Nations Convention on the Rights of Persons with Disabilities: New Era or False Dawn?" 34 Syracuse J. Int'l. L. \& Com. 563 (Spring, 2007): 569. An extreme description, but perhaps apt in extreme circumstances where the disabled individual cannot "make such decisions as where to live and with whom, what to eat or buy, whether or where to work, for whom to vote, or whom to befriend, have sex with, or marry" (see Kanter, supra note 4: 561).
} 


\section{NATIONAL APPROACHES TO DETERMINING THE LEGAL CAPACITY FOR DISABLED PERSONS PRIOR TO THE CONVENTION}

There have been different types of legal analyses utilized for determining the legal capacity of disabled persons under national law. These can generally be categorized as three different types of tests: the status test, the functional test, and the outcome test.

Pursuant to the status test, once it is determined that an individual has a certain kind of disability, the person automatically lacks the legal capacity to do a certain thing. Examples of the status test include an automatic rule that a person with a kind of psychological disorder cannot adopt a child, or that a blind person cannot conclude a bank transaction without assistance. ${ }^{13}$

Under the functional test, a two-step analysis is employed. First, a determination is made whether the person has a disability. Second, if so, does this disability render the person legally incapacitated for the action in question? Thus, under the functional test, unlike the status test, the analysis does not end once it is determined that the person has a disability. Next, legal and/or medical experts must determine how the disability affects the person's legal capacity to perform a specific task. Applying this test in civil cases, the question is whether a mental disability has the capacity to understand and enter into a contract. In criminal cases, the question may be whether the defendant has the capacity to determine right from wrong. ${ }^{14}$

In the outcome test, the disabled person's specific decision or action is analyzed to determine if he or she had the legal capacity to make that decision or take that action. A classic example of the use of the outcome test would be the review of a mentally disabled person's decision to discontinue medical/psychological treatment. In essence, the review is conducted backwards - the decision is examined to see if a reasonably capable person could make such a choice. If not, the decision is blocked. ${ }^{15}$

There are serious flaws in all of these tests. For the status test, the problem is obvious and even gaping - equating disability automatically with legal incapacity. There is no review as to whether the given disability in fact incapacitates the person from undertaking a specific action. Sometimes there is also no sense of proportionality whatsoever, and the mere existence of a disability will completely strip a disabled person of all legal capacity. ${ }^{16}$ In extreme cases, even the existence

\footnotetext{
13 See Dhanda, supra note 9: 431.

14 Ibid.

15 Ibid. : 431-432.

16 Ibid. : 432.
} 
of a sensory disability, such as blindness or deafness, could cause the person's complete loss of legal capacity. ${ }^{17}$

As applied, the other tests are problematic as well. In applying the functional test, many legal and medical experts, once they have determined a disability exists, automatically presume that this disability makes the person legally incapable. Likewise, the outcome test is often guided by what decision would be socially acceptable at the time. So, in practice, the functional approach and the outcome test are often effectively the same as the status test: once it is determined that a disability exists, the person is deemed legally incapable. ${ }^{18}$

Disabilities rights advocates attempted to correct the flaws in national determinations of legal capacity by proposing the following key changes in state policy: Presume that all disabled persons have legal capacity, rather than vice versa; and distinguish the incapacity to make a decision from the inability to communicate a decision. Where a disabled person needs assistance to exercise his or her capacity, the state should supply this assistance instead of declaring the person incapable. Guardianship should be only be used as a last resort. The focus should be on increasing a disabled person's ability to exercise his or her own right of legal capacity, rather than transferring this right to the state and/or a third person appointed by the state. ${ }^{19}$

These efforts bore fruit in the burgeoning expansion of disability rights law at the international level, particularly with respect to the issue of legal capacity.

\section{INTERNATIONAL STANDARDS FOR DETERMINING THE LEGAL CAPACITY OF DISABLED PERSONS}

\subsection{EUROPEAN STANDARDS}

The Council of Europe Recommendation on the Legal Protection of Incapable Adults ("Recommendation") was adopted on February 23, 1999. ${ }^{20}$ It is applicable to adult disabled persons who cannot make decisions about their own personal and economic affairs; cannot understand or act upon such decisions; and cannot protect their interests. Its governing principles call for states to maintain respect for human rights, flexibility in the state's response to such situations, and a maximum preservation of capacity. That is, a loss of some capacity does not necessarily mean

17 See Lawson, supra note 12: 569 (noting that 7 Latin American countries treated blind and/or deaf persons in this manner).

${ }^{18}$ See Dhanda, supra note 9: 432.

19 Ibid. : 433-439.

20 Recommendation No. R(99) 4 of the Committee of Ministers to Member States on Principles Concerning the Legal Protection of Incapable Adults, Council of Eur. Comm. of Ministers, Principle 6 (1999) // http://www.coe.int/t/dg3/healthbioethic/texts_and_documents/Rec(99)4E.pdf (last accessed April 20, 2011) (hereinafter "Recommendation"). 
a loss of all capacity. Limitations must be necessary, proportional, and protect his/her interests. ${ }^{21}$

The state's procedure for making determinations of incapacity is also regulated. Critically, due process guarantees are provided to the disabled person. Even after a decision of incapacity has been made, the state must ensure adequate control over any limitations that are put in place. This includes providing the disabled person the opportunity for appeal and periodic review, and a reasonable limitation of the duration of any such restrictions. ${ }^{22}$

In the event a guardian is appointed, the state must ensure that they are qualified. Further, the powers of guardians should be limited to the extent necessary to act only in areas where the disabled person cannot do so on his or her own. In any event, the conferment and exercise of "such powers should not deprive the adult of legal capacity." ${ }^{23}$ Provisions should also be made for the legal liability of guardians "for wrongful acts, negligence or maltreatment ... ." ${ }^{24}$ At the same time, the issue of the guardian's compensation and reimbursement for costs/expenses should be addressed. ${ }^{25}$

The Recommendation also contains special guidelines for interventions in the health field. Where it is not possible to obtain the person's consent, interventions are permitted where they benefit the patient and authorization is provided by the guardian. In the case of treatment for mental health, intervention is only permitted when serious harm to the patient's health would otherwise result. ${ }^{26}$

Of course, the Recommendations are only that: non-binding suggestions of best practices for the members of the Council of Europe. Yet, with the progression of time, they have become "soft law" in the best sense of that term. While nonbinding in and of itself, the principles set forth in the Recommendations have seeped into enforceable European "hard law".

There has not been a specific provision in European law expressly dealing with the issue of legal capacity for disabled people. However, Article 8 of the European Convention on Human Rights has been judicially construed as applying to the deprivation of rights of disabled people, under the guise of loss of legal capacity. Article 8 , entitled "right to respect for private and family life," provides that:

1. Everyone has the right to respect for his private and family life, his home and his correspondence.

\footnotetext{
${ }^{21}$ Ibid.: Part I.

22 Ibid.: Part III.

${ }^{23}$ Ibid.: Part IV, Principle 18, paragraph 2.

${ }^{24}$ Ibid.: Part IV, Principle 20, paragraph 2.

${ }^{25}$ Ibid.: Part IV, Principle 21.

${ }^{26}$ Ibid.: Part V.
} 
2. There shall be no interference by a public authority with the exercise of this right except such as is in accordance with the law and is necessary in a democratic society in the interests of national security, public safety or the economic well-being of the country, for the prevention of disorder or crime, for the protection of health or morals, or for the protection of the rights and freedoms of others. ${ }^{27}$

The European Court of Human Rights has protected the rights of such persons in various circumstances involving the loss of legal capacity, interpreting Article 8 in light of the principles set forth in the Council of Europe's Recommendation. Recent examples include the Court's decision in $X$ v. Croatia. ${ }^{28}$ In that case, a schizophrenic drug addict and mother was deprived of her legal capacity by a Croatian court. The Croatian court later severed her connection with her child, an action that was approved by her guardian. Subsequently, the child was adopted. The Court in Strasbourg ruled that Croatia violated the ECHR, since the blanket loss of all of X's legal capacity was too broad and not proportional to her disability. Importantly, while she may not have been legally competent in some areas, she nevertheless may have retained the capacity to contest the adoption and loss of her child. In reaching this conclusion the Court cited the Recommendation's provisions on flexibility in legal response; maximum reservation of capacity; proportionality; right to be heard in person; and duration review and appeal as "relevant international law."29

While not expressly citing the Recommendation, the Court used similar reasoning in its decision in Zehentner v. Austria. ${ }^{30}$ In that case, a person suffering from paranoid psychosis, and for whom a guardian was appointed, had been evicted from her house. The house was then sold to pay a debt. The Austrian court refused her untimely appeal challenging her eviction and the subsequent sale. Upon review, a violation of Article 8 was found by the Court. Because of her disability and given the circumstances of the case, Austria should have been flexible with its time deadlines for making an appeal. The Court reasoned that:

Persons who lack legal capacity are particularly vulnerable and states may thus have a positive obligation under art. 8 to provide them with specific protection by the law. While generally there may be good reasons for having an absolute time limit for lodging an appeal against a judicial sale of real estate, specific

\footnotetext{
27 See European Convention on Human Rights and Fundamental Freedoms, E.T.S. No. 005 (opened for signature Nov. 4, 1950; entered into force Sept. 3, 1953): Article 8 (hereinafter ECHR). Article 6.1, dealing with the right to a fair trial, has also been implicated in protecting the rights of persons whose legal capacity was at issue.

${ }^{28}$ X. v. Croatia, 51 E.H.R.R. 20 (2010).

${ }^{29}$ Ibid.: *522-523 (Westlaw pagination).

30 Zehentner v. Austria, 52 E.H.R.R. 22 (2011).
} 
justification would be required where a person lacking legal capacity is concerned. ${ }^{31}$

\subsection{INTERNATIONAL STANDARDS}

The Convention on the Rights of Persons with Disabilities (CRPD or Convention ${ }^{32}$ ) is the landmark international convention to protect the rights of people with disabilities. It was adopted on December 13, 2006 by the United Nations (UN) General Assembly, and came into effect after the 20th state ratification in May, 2008. ${ }^{33} 147$ states are signatories to the CRPD, and 99 states have ratified it, including Lithuania. ${ }^{34}$

Article 12, entitled Equal recognition before the law, deals with the question of legal capacity. It consists of 5 parts:

1. States Parties reaffirm that persons with disabilities have the right to recognition everywhere as persons before the law.

2. States Parties shall recognize that persons with disabilities enjoy legal capacity on an equal basis with others in all aspects of life.

3. States Parties shall take appropriate measures to provide access by persons with disabilities to the support they may require in exercising their legal capacity.

4. States Parties shall ensure that all measures that relate to the exercise of legal capacity provide for appropriate and effective safeguards to prevent abuse in accordance with international human rights law. Such safeguards shall ensure that measures relating to the exercise of legal capacity respect the rights, will and preferences of the person, are free of conflict of interest and undue influence, are proportional and tailored to the person's circumstances, apply for the shortest time possible and are subject to regular review by a competent, independent and impartial authority or judicial body. The safeguards shall be proportional to the degree to which such measures affect the person's rights and interests.

5. Subject to the provisions of this article, States Parties shall take all appropriate and effective measures to ensure the equal right of persons with disabilities to own or inherit property, to control their own financial affairs and to have equal access to bank loans, mortgages and other forms of financial credit,

\footnotetext{
${ }^{31}$ Ibid.: *753 (Westlaw pagination).

32 Convention on the Rights of Persons with Disabilities, G.A. Res. 61/611, U.N. Doc. A/RES/61/611, art.12 (Dec.6, 2006) // http://www.un.org/esa/socdev/enable/rightsconvtexte.htm (hereinafter CRPD or Convention).

${ }^{33}$ See Janet Lord and Michael Ashley Stein, "The Domestic Incorporation of Human Rights Law and the United Nations Convention on the Rights of Persons with Disabilities," 83 Wash. L. Rev. 449 (November, 2008): 450 .

${ }^{34}$ See Convention and Optional Protocol Signatures and Ratifications (For the Convention on the Rights of Persons with Disabilities, provided by the United Nations "Enable" website) // http://www.un.org/disabilities/countries.asp?navid=17\&pid=166 (last accessed April 20, 2011).
} 
and shall ensure that persons with disabilities are not arbitrarily deprived of their property. ${ }^{35}$

The Convention represented something of a sea change in how a disabled person's legal capacity should be treated by the state. ${ }^{36}$ Prior national models appeared to presume incapacity more often than not, and then total incapacity rather than partial. The focus was on the legal rights of guardians, standing in the place of the disabled person. Under the Convention, Article 12 starts with the presumption that all disabled people are considered to be persons under the law, and that they enjoy equal rights to legal capacity as enjoyed by all other persons in society. Thus, "[i]nstead of parentalistic guardianship laws which substitute a guardian's decision for the decision of the individual, the CRPD's supported-decision making model recognizes first, that all people have the right to make decisions and choices about their own lives." ${ }^{37}$

Instead of focusing on depriving disabled people of such decision making capacity, the Convention turns this idea on its head. The CRPD restates the issue as one of the obligation of the state to provide assistance where necessary, so that the disabled person may exercise his or her legal capacity. ${ }^{38}$ This process can be described as "supported decision making," 39 and may be used "on one occasion or always, ${ }^{\prime \prime 40}$ consistent with the principle of proportionality.

Still, the line between a guardian in the role of a "supporter" of a person exercising their decision making capacity, and someone who is in fact assuming that capacity, can still sometimes be blurred. Consequently, the Convention implements various safeguards protecting the basic rights of the disabled person in guardianship situations to prevent abuse. Article 12.4 provides that "[s]uch measures should "respect the rights, will and preferences of the person, [be] free of conflict of interest and undue influence, [be] proportional and tailored to the person's circumstances, apply for the shortest time possible and [be] subject to

35 See Convention, supra note 32: Article 12.

36 See, e.g., Aaron Dhir, "Human Rights Treat Drafting Through the Lens of Mental Disability: The Proposed International Convention on the Protection and Promotion of the Rights and Dignity of Persons with Disabilities," 41 Stan. J. Int'I L. 181 (Summer, 2005): 182 (noting that prior to the Convention, only one binding international human rights treaty "even refer[red] to the issue of disability, despite the acknowledged fact that persons with disabilities make up one of the largest global minority groups, and that the rights of this class of persons have been systematically violated in virtually all societies.").

37 See Kanter, supra note 4: 563.

${ }^{38}$ A dispute in drafting this Article arose over whether the legal capacity to possess rights and the legal capacity to act were two different things. The final draft is ambiguous, but does seem to delineate some distinction between the possession of legal capacity, and the exercise of this capacity. No limitation is permitted on possession of legal capacity (as emphasized by Article 12.5, prohibiting the deprivation of a disabled person's right to inherit or own property, for example), but there may be some "support" from a guardian on its exercise, with appropriate limitations to protect against abuse (see Lawson, supra note 12: 597).

${ }^{39}$ See Salzman, supra note 3: 180 (explaining "[t]he concept of supported decision making is predicated on the basic principle that all people are autonomous beings who develop and maintain capacity as they engage in the process of their own decision making, even if some level of support is needed to do so.").

40 See Kanter, supra note 4: 563-564. 
regular review by a competent, independent and impartial authority or judicial body."' the disabled person, should be in place to "help ensure that the human rights of a person with a disability are not curtailed or abused." ${ }^{42}$

In sum, Article 12 "is a clear affirmation of the need to move away from systems of substituted decision-making to ones of supported decision-making. It is a ringing endorsement, not simply of the principle of equality, but also of the values of dignity and autonomy." ${ }^{\prime 3}$

\section{LITHUANIAN LAW AND PRACTICE ON THE LEGAL CAPACITY OF DISABLED PERSONS}

The concept of civil capacity under Lithuanian law means that a natural person shall enjoy full enjoyment of civil rights (passive civil capacity) and he, by his acts, fully exercises all of his civil rights and shall assume civil obligations (active civil capacity). ${ }^{44}$

The Lithuanian Civil Code states that a "natural person who as a result of mental illness or imbecility is not able to understand the meaning of his actions or control them may be declared incapable". ${ }^{45}$ Lithuania's Law on Mental Health Care provides that a person may only be declared as incapable only in judicial proceedings. ${ }^{46}$

A mentally ill person is defined as a "person ill with a mental disease". ${ }^{47}$ Mentally ill persons possess all political, economic, social and cultural rights. ${ }^{48}$ Thus, only establishing a person's mental disease is not grounds for suspending that person's rights. Only in situations when the mental condition of the person is such that the person is not able to understand the meaning of his actions or control them may the court declare him to be incapable. Such a person could not take care of himself, nor enter decisions and be responsible for them. Only after having established such facts (both medical and legal criteria) may the aim of the process

\footnotetext{
${ }^{41}$ See Buschbacher Connelly, supra note 6: 133 (quoting Article 12.4 of the Convention).

42 Ibid. One commentator also makes the persuasive point that for such procedural safeguards to be effective, the disabled person should be provided with competent counsel by the state. See Michael Perlin, "'I Might Need a Good Lawyer, Could be Your Funeral, My Trial': Global Clinical Education and the Right to Counsel in Civil Commitment Cases," 28 Wash. U. J.L. \& Pol'y 241 (2008).

${ }^{43}$ See Lawson, supra note 12: 597.

${ }^{44}$ Civil Code of the Republic of Lithuania, Official Gazette (2000, no. VIII-1864): Articles 2.1 and 2.5.

${ }^{45}$ Ibid. : Article 2.10.

${ }^{46}$ Law on Mental Health Care of the Republic of Lithuania, Official Gazette (1995, No I-924) [as amended on 5 July 2005 No X-309]: Article 4 ("A mentally ill person who is not able to understand the meaning of his actions or control them may in judicial proceedings be declared incapable").

${ }^{47}$ Ibid.: Article 1.

${ }^{48}$ Ibid.: Article 3.
} 
for declaring a person to be incapable set forth in the Lithuanian Civil Code be reached. ${ }^{49}$

Under the Lithuanian Civil Procedure Code, the judge, when preparing the hearing for such a case, must appoint court psychiatric experts. ${ }^{50}$ The aim of having such expertise is to determine whether a person is mentally ill and whether he understands the meaning of his actions or is able to control them. ${ }^{51}$ However, such expert reports may be misleading ${ }^{52}$, because they could be interpreted by the parties to the case as evaluating not only medical criteria, but also legal criteria as well. ${ }^{53}$ As is stated in the Lithuanian Supreme court's decision ${ }^{54}$, a case declaring a person as incapable cannot be decided in too technical a manner, applying only the medical criteria set forth in the experts' reports. Even though it is within the court's power to decide whether to declare a person as incapable, this does not also mean that the court is always empowered to make such a declaration based solely upon the report of a medical expert.

All evidence must be evaluated, especially the specific facts pertaining to whether a person can or cannot understand his actions and control them. ${ }^{55}$ This means that other evidence must be collected in the case, apart from the reports of experts. ${ }^{56}$ Such court decisions must be made in accordance with the Law on Mental Health Care, where it is stated that the mental illness must be severe, and the potential danger caused by his actions (to commit serious harm to himself or others) must be real. ${ }^{57}$ A severe mental illness could be ascribed to such a person, who has the most serious and long-term mental health disorder, which permanently and totally restrict his ability to orient himself in society, to work, to integrate, to be economically independent, to make decisions for himself and to respond to

\footnotetext{
${ }^{49}$ Civil Code of the Republic of Lithuania in article 3.238 states, that "the aim of declaring person as incapable is exercising, protecting and defending the rights and interests of that person" (Civil Code of the Republic of Lithuania, supra note 44: Article 3.238).

50 Civil Procedure Code of the Republic of Lithuania, Official Gazette (2002, no. IX-743): Articles 466, 467.

${ }^{51}$ A.Č. v. V.Č., M.Č., P.Č., Dainai medical station, Šiauliai regional court (2009, 2A-229-45/2009); A.G. v. Marijampolé city municipality's administration, Department of social affairs, Social support subdivision, Kaunas regional court (2009, 2A-102-153/2009).

52 T.L. v. Kèdainiai district municipality's administration, Department of culture and education, Social support subdivision, Panevėžys regional court (2009, 2A-393-544/2009).

53 Persons ability to understand the meaning of his actions or control them.

54 V. ̌́., F. ̌. ., I.M.D. v. Kaunas city municipality's administration, Department of social affairs, Health subdivision, The Supreme Court of Lithuania (2008, no.3K-3-370/2008).

55 B.L., F.L., R.L. V. Tauragè district municipality's administration, Social support subdivision, Klaipèda regional court (2008, 2A-302-524/2008).

56 See V.Č., F.C., I.M.D., supra note 54. The European Court of Human Rights has said that the decision of a judge to decide a case on the basis of documentary evidence was unreasonable and in breach of the principle of adversarial proceedings enshrined in Article $6 \S$ 1of the Human Rights Convention (see Shtukaturov v. Russia, 2008 WL 4264284 (European Court of Human rights, Application no. 44009/05)). ${ }^{57}$ Law on Mental Health Care of the Republic of Lithuania, supra note 46: Article 27 ("A person who is ill with a severe mental illness and refuses hospitalization may be admitted involuntarily to the custody of the hospital only if there is real danger that by his actions he is likely to commit serious harm to: 1 ) his health, life; 2) to the health, life of others").
} 
them. ${ }^{58}$ In such situations, the court must apply the principle of the maximum capacity preservation of mentally ill persons, under which attention must be given to the fact that there may be varying degrees of inability to understand the meaning of his actions and to control them, and thus the decision to declare a person as incapable must be used only as an Ultima Ratio measure. ${ }^{59}$ The court's decision must be based on the application of the principle of proportionality, to decide whether restrictions will be proportionate to the legitimate purpose of protecting a person's or others' health or interests ${ }^{60}$, i.e. to decide that the mental illness and inability to understand the meaning of his actions and to control them is so severe that it allows one to reasonably determine that the person requires care. ${ }^{61}$

However, Lithuanian court practice shows ${ }^{62}$ that in incapacity cases usually only medical criteria are applied, with scant attention paid to other criteria. Sometimes it is enough to have only a diagnosis of mental illness, and restrictions will be imposed. No evaluation of a person's ability to act in certain situations is made. So it can be said that a person's disability could be a reason for declaring a person as incapable. When a person is declared by the court as incapable, the person's active civil capacity is suspended, and he will be placed under guardianship. Such situations sometimes leads to the curiosity of a normal employee and socially adapted person being declared incapable and losing his right to work, even though he is fully able and willing to maintain his employment. ${ }^{63}$

The Civil Code of the Republic of Lithuania allows the court to impose limited active civil capacity only upon those persons who are abusing alcohol, drugs,

${ }^{58}$ See V.Č., F.Č., I.M.D., supra note 54.

59 E.Š. V. R.Š., F.Š., H.Š., Širvintos district municipality's administration, Health and Social support subdivision, Vilnius regional court (2009, 2A-956-302/2009); see also judgement of the European Court of Human Rights in: Matter v. Slovak Republic, 31 E.H.R.R. 32 (2001) [Section II] (length of proceedings relating to deprivation of legal capacity on mental health grounds violated Art. $6 \S 1$ ).

60 A.G. V. Marijampole city municipality's administration, Department of social affairs, Social support subdivision, supra note 51. Similar provisions are mentioned in Article 8 of Recommendation $\operatorname{Rec}(2004) 10$ of the Council of Europe Committee of Ministers to member states concerning the protection of the human rights and dignity of persons with mental disorder (Adopted by the Committee of Ministers on 22 September 2004 at the 896th meeting of the Ministers' Deputies).

${ }^{61}$ See V.Č., F.Č., I.M.D., supra note 54.

62 Ibid.; see also B.L., F.L., R.L. V. Tauragè district municipality's administration, Social support subdivision, supra note 55; A.G. v. Marijampole city municipality's administration, Department of social affairs, Social support subdivision, supra note 51 ; T.L. v. Kedainiai district municipality's administration, Department of culture and education, Social support subdivision, supra note 52; A. ̌. v. V.Č., M. ̌., P.Č., Dainai medical station, supra note 51; E.S. V. R.Š., F.Š., H.Š., Širvintos district municipality's administration, Health and Social support subdivision, supra note 59; G.A. v. A.S., J.S., R.S., A.S., Utena district municipality's administration, Social support subdivision, Panevèžys regional court (2010, 2A-8-280/2010); G.L. V. Vilnius city municipality's administration, Social support subdivision, The Supreme Court of Lithuania (2007, 3K-3-328/2007).

63 "Neveiksnumo problematika Europos Sajungos deklaruojamy vertybiu kontekste" (The problems of incapacity in the context of European Union declared values), VSt "Globali iniciatyva psichiatrijoje": 4 // www.old.gip-vilnius.It/leidiniai/GIP_neveiksnumas.pdf (accessed March 10, 2010). 
narcotic or toxic substances. ${ }^{64}$ In such cases, after a person's capacity has been judicially limited, he could be placed under a guardianship. ${ }^{65}$ Physical or mental disability is not a basis to declare a person as having limited active civil capacity and to give him the opportunity to self-implement at least some of his rights. In other situations the rules of guardianship may be applied, when it is clear what level of special care for the person is necessary. ${ }^{66}$ However, such an option can only be exercised by persons with a palliative or addictive disease, because mental illness is specified only as a basis to declare a person as fully incapable.

\section{LITHUANIA'S NON-COMPLIANCE WITH INTERNATIONAL STANDARDS AND SUGGESTIONS FOR REFORM}

The protection of the rights of the most vulnerable social group - disabled people - remains a problematic sphere in Lithuania. Despite existing regulations protecting fundamental human rights, there are still instances where a disability is used as the basis to deprive a person of almost all of his or her rights, including the right to work, the right to property, etc., while declaring that person as "incapable." The person also loses the right to apply to the court, even in situations where he is seeking to protect his own interests in the court.

It must be noted that the concepts of disability and incapacity must be used very carefully, because in different situations the meaning of these otherwise similar words can be highly divergent. The World Health Organization defines "disability" as follows:

Disabilities is an umbrella term, covering impairments, activity limitations, and participation restrictions. An impairment is a problem in body function or structure; an activity limitation is a difficulty encountered by an individual in executing a task or action; while a participation restriction is a problem experienced by an individual in involvement in life situations. Thus disability is a complex phenomenon, reflecting an interaction between features of a person's body and features of the society in which he or she lives. ${ }^{67}$

\footnotetext{
${ }^{64}$ Civil Code of the Republic of Lithuania, supra note 44: Article 2.11 ("Where natural persons abuse alcoholic beverages, drugs, narcotic or toxic substances the court may impose restrictions on their civil capacity").

${ }^{65}$ Curatorship is established with the aim of protecting and defending the rights and interests of a person of limited active capacity. The curator gives consent for the ward of limited active capacity to enter into a transaction the ward would not be permitted to enter into independently and shall also help the ward of limited competence to exercise his or her other rights and duties as well as protect his or her interests against third parties (ibid: Article 3.239. and Article 3.240).

${ }^{66}$ Ibid.: Article 3.279 ("At the request of a natural person of full active capacity incapable of exercising his or her rights or of performing his or her duties due to health reasons may be placed under curatorship").

67 "Health topics," World Health Organization // http://www.who.int/topics/disabilities/en/ (accessed April 9, 2010).
} 
Thus we can say that disability describes a health condition, whereas incapacity can specifically refer to a concept of law (i.e., it is a legal term) that designates the restriction of a person's ability to perform certain legal acts. Mixing the concepts of disability and incapacity could lead one to interpret legal acts in a misleading way. The rights of incapable and disabled individuals, respectively, could be completely different.

Under the Lithuanian Civil Code incapacity is used only when describing a person's legal status, but in some other legal acts we can find incapacity instead of disability described. For example, the Committee of Ministers of the Council of Europe in its Recommendation to member states uses the term incapacity. They described incapacity as the condition of people who, "by reason of an impairment or insufficiency of their personal faculties, are incapable of making, in an autonomous way, decisions concerning any or all of their personal or economic affairs, or understanding, expressing or acting upon such decisions, and who consequently cannot protect their interests". ${ }^{68}$ In other words, they described disability but not incapacity. Disability refers mainly to a functional limitation in ordinary activity; incapacity concerns people who are unable to perform certain acts because of a court decision. Although the terms overlap, they are conceptually distinct. Clarifying these distinctions is important for this work: being disabled does not in all cases justify branding a person as reason incapable. Such distinction must be made in subsequent Lithuanian legal acts.

A person's disability does not always provide the basis for suspending his active civil capacity. The process of declaring a person as incapable reveals some problems which could lead to a violation of human rights.

When analyzing prosecutors' activity in defending the rights of social protected people, the prosecutor general's office of the Republic of Lithuania found that a person's physical disease or inability to care for themselves is often provided as a basis for declaring the person as incapable in the papers filed by the prosecutors with the court. ${ }^{69}$ The right to a private life ${ }^{70}$ includes the right to maintain one's identity and personal development, and the right to establish and develop relationships with other human beings and the outside world. ${ }^{71}$ Respecting a person's private life also means that a court must guarantee that no person with merely a formal diagnosis of mental illness should hastily be determined to be

\footnotetext{
68 See Recommendation, supra note 20: part I, sec. 1.

69 Summing-up note regarding decisions presented by prosecutors defending rights of social protected persons, Prosecution Service of the Republic of Lithuania (2008, no.13.13-6).

70 See ECHR, Article 8 ("Everyone has the right to respect for his private and family life, his home and his correspondence."). See also The Constitution of the Republic of Lithuania, Article 22, Official Gazette (1992, no. 33-1014) ("The private life of a human being shall be inviolable.").

71 See, for example, Burghartz v. Switzerland, 31 E.H.R.R. 32 (2001): paragraph 47; and Friedl v. Austria, 21 E.H.R.R. 83 (1996): paragraph 45.
} 
incapable. ${ }^{72}$ When preparing a request by a prosecutor to establish person as incapable, it is usually stated that "the person is incapable due to his physical and mental illness, and therefore he cannot understand the meaning of his actions and control them". ${ }^{73}$ The character of mental illness must be presented to the court with the arguments why a person cannot understand and control his actions by which he can evoke a danger to himself or to surrounding people. ${ }^{74}$ While investigating the grounds for declaring a person as incapable, the courts wrongly determine the existence of medical and legal criteria. Therefore, the person is determined to be incapable only after the status of mental disorder is established. There is no analysis about whether the person is capable to act in certain situations. ${ }^{75}$ Such a practice shows that sometimes a person with a physical disability can be declared as incapable, which, of course, violates human rights. For that reason, the criteria utilized when declaring a person incapable must be analyzed in detail.

In May, 2010 Lithuania ratified the UN Convention on the Rights of Persons with Disabilities and its Optional protocol. ${ }^{76}$ Article 12 of that Convention provides that:

"persons with disabilities have the right to recognition everywhere as persons before the law[, that] persons with disabilities enjoy legal capacity on an equal basis with others in all aspects of life"[, and that] "measures relating to the exercise of legal capacity respect the rights, will and preferences of the person, are free of conflict of interest and undue influence, are proportional and tailored to the person's circumstances, apply for the shortest time possible and are subject to regular review by a competent, independent and impartial authority or judicial body". ${ }^{77}$

Such a provision may well be considered to be one of the most important in conjunction with the defense of human rights. Recognition everywhere as persons before the law means that if a person for some reason (whether age, illness, disability, etc.) could not properly implement his rights and duties, there must be a legal mechanism which could guarantee his rights and freedoms. Lithuania's Law on Mental Health Care provides that a person may only be declared as incapable in

\footnotetext{
72 B.L., F.L., R.L. v. Tauragè district municipality's administration, Social support subdivision, supra note 55.

${ }_{73}$ Summing-up note regarding decisions presented by prosecutors defending rights of social protected persons, supra note 69.

${ }_{74}$ These criteria must be evaluated in all cases deciding whether to announce person as incapable. They rise from the Article 2.10 of the Civil Code of the Republic of Lithuania.

${ }_{75}$ Summing-up note regarding decisions presented by prosecutors defending rights of social protected persons, supra note 69.

${ }_{76}$ Law on ratification of the UN Convention on the Rights of Persons with Disabilities and its Optional protocol, Official Gazette (2010, no. XI-854).

77 Convention, supra note 32: Article 12.
} 
judicial proceedings. ${ }^{78}$ The principle of proportionality mentioned in the Convention on the Rights of Persons with Disabilities means ${ }^{79}$ that it is not enough to have only the diagnosis of illness, but that other circumstances must be evaluated, and the measures imposed by the court must be necessary in order to attain the specified objectives: to save person from harm to himself and to protect other peoples' health and/or property. ${ }^{80}$

In evaluating Lithuanian law when implementing the rights of disabled it should be noted that Lithuania does not fully comply with the Convention on the Rights of Persons with Disabilities and the principle of proportionality. ${ }^{81}$ It is impossible for mentally ill persons in accordance with the severity of their illness to use at least some of their rights and freedoms within their discretion, because Lithuanian law allows only for a declaration that a person is fully - and not partially - incapable.

The option of restricting a person to only a limited active civil capacity should be expanded beyond cases involving alcohol or drug addiction. If applied to cases involving mental illness, the court could find that a person has mental health problems for which he is only partly capable to perform actions which can have legal consequences. There would not be any difficulties for the court to evaluate what actions could be done by the person himself, because increased vulnerability of people with mental diseases requires greater judicial attention. ${ }^{82}$ Such attention means that courts must analyze in detail the mental illness of the person, its impact on his social life, health, property interests, the security of his or his surroundings, and to evaluate the person's capacity to act in the various areas of social life, especially those in which prohibitions and (or) restrictions could be imposed. ${ }^{83}$ Such evaluation could not be performed by solely relying upon the reports of participating medical experts. When undertaking such a complex evaluation of a person's social environment, his rehabilitation, working, educational and social

\footnotetext{
78 Law on Mental Health Care of the Republic of Lithuania, supra note 46: Article 4 ("A mentally ill person who is not able to understand the meaning of his actions or control them may in judicial proceedings be declared incapable").

${ }^{79}$ Convention, supra note 32: Article 12.

80 The principle of proportionality was explained in several rulings of the Constitutional Court of the Republic of Lithuania. The court said, that "it is necessary to assess whether the measures established in the law are in compliance with legitimate objectives that are important to society, whether these measures are necessary in order to attain the specified objectives and whether these measures do not restrict the rights and freedoms of the person apparently more than necessary in order to attain the said objectives" (On the compliance of article 3 (wording of 26 June 2001), article 4 (wordings of 26 June 2001 and 3 April 2003), paragraph 3 of article 6 (wording 26 June 2001) and paragraph 1 of article (wording of 26 June 2001) of the Republic of Lithuania law on the restraint of organized crime with the Constitution of the Republic of Lithuania, Ruling of the Constitutional Court of the Republic of Lithuania (December 29, 2004), Official Gazette (2005, no. 1-7)).

${ }^{81}$ See Convention, supra note 32: Article 12.

82 See Herczegfalvy v Austria, 15 E.H.R.R. 437 (1993): paragraph 82 ("the position of inferiority and powerlessness which is typical of patients confined in psychiatric hospitals calls for increased vigilance in reviewing whether the Convention has been complied with").

83 See V.Č., F. C.., I.M.D. v. Kaunas city municipality's administration, Department of social affairs, Health subdivision, supra note 54.
} 
skills, there will be a need for the court to consider a wider range of experts (including psychologists, social workers, social educators, rehabilitation specialists) ${ }^{84}$.

While Lithuania ratified the UN Convention on the Rights of Persons with Disabilities, its Civil Code still does not conform with all the provisions of that Convention. There is no periodical review of the courts' decisions declaring a person as incapable, because all actions on behalf and in the name of that person could be concluded only by his guardian. ${ }^{85}$ While the decisions of the European Court of Human Rights suggest that mental illness may justify some restrictions on a person's ability to apply to the court, these restrictions may not entirely remove that right. ${ }^{86}$

\section{CONCLUSIONS}

Lithuania's approach to determining the legal capacity of disabled persons resembles the functional test in form, and the status test in practice. In theory, Lithuania employs a two-stage, mixed medical/legal analysis to determine if a disabled person loses his or her legal capacity and is entrusted to the care of a guardian. First, it is medically determined if an individual has a serious mental disability. Second, a determination is made whether or not this disability is so severe as to render the person unable to care for him or herself, make decisions, to work, etc. If this is the case, a court may restrict the disabled person's legal capacity, and appoint a guardian.

In practice however, a de facto status test is used. The courts place too great a reliance on the opinion of experts, and once these experts conclude the person is severely disabled, almost always the person will be stripped of his or her legal capacity. No further analysis is made to determine whether or not whether the disability actually renders the person incapable of carrying out some or all functions in everyday life.

Compounding the problem is the Lithuanian courts "all or nothing" approach with respect to the question of capacity. Once a disabled person passes the legal threshold of incapacity, he or she is rendered legally incapable in every respect: incapable to work, and incapable of making all financial, medical and life decisions. Finally, once such a decision on incapacity has been made, there is no meaningful

\footnotetext{
84 "Žmogaus teisiú igyvendinimas Lietuvoje. Apžvalga" (The implementation of human rights in Lithuania. Review), Žmogaus teisiu stebejimo institutas // http://www.e-library.It/resursai/DB/ZTSI/2003/zt_pr03_15.pdf (accessed June 27, 2010).

85 "The guardian and the curator shall represent their wards under law and shall defend the rights and interests of legally incapable persons or persons of limited active capacity without any special authorization" (Civil Code of the Republic of Lithuania, supra note 44: Article 3.240).

${ }^{86}$ See Golder v. The United Kingdom, 1 E.H.R.R. 524 (1979-80).
} 
opportunity for the disabled person to review this decision. Such a decision to apply to the court for a review is held by the guardian, who may or may not be willing to take this step, even if changes in the degree of the person's disability would warrant it.

These practices unquestionably violate both the Council of Europe's Recommendations and the Convention. Article 12 of the Convention starts from the premise that disabled people are legal persons, and have full legal capacity. In some circumstances, a disabled person may need support in exercising his or her capacity, but such support must be proportional to the extent required by the disability. It may only be needed on one occasion, for example. A guardian should not in any case exercise all the rights of a disabled person, if that person were quite competent in making some decisions on his or her own. The Convention also mandates that an adequate mechanism be in place to ensure any decisions restricting or limiting the exercise of capacity are limited in duration and subject to impartial review.

In sum, while Article 12.3 expressly requires that any limits must be "proportional and tailored to the person's circumstances, apply for the shortest time possible and are subject to regular review by a competent, independent and impartial authority or judicial body, ${ }^{\prime 87}$ Lithuanian practice is otherwise.

Yet, at the same time, there are positive signs. The Lithuanian Prosecutor's office has issued a report criticizing Lithuanian legal practice in this regard. Often the biggest obstacle to reform is the failure to recognize that a problem exists. This is not the case in Lithuania.

Moreover, there are already some structures in place that would make reform easier to implement. A process already exists for persons with drug and/or alcohol addictions to lose only part of their legal capacity, in proportion to the limitations caused by their respective addictions. This process should be immediately extended to individuals with different disabilities, in accord with the Convention's requirements on proportionality.

Otherwise, as even the Lithuanian Supreme Court has suggested, the process for determining incapacity must not be made in too mechanical a fashion, with an over-reliance on expert opinions. A detailed inquiry should be made in each case to determine to what extent, if any, a disabled citizen requires support in making decisions and functioning in society. Further, an automatic review should be made of all incapacity decisions, so that court errors and changed conditions that may warrant a change of status may be presented. The use of special law school clinics on disability rights, where professors, lawyers and law students provide assistance

\footnotetext{
${ }^{87}$ See Convention, supra note 32: Article 12.3.
} 
to disabled people in challenging their loss of capacity, should be examined in this regard..$^{88}$

To the extent that Lithuania continues down this path of reform, it will - as it has in the past - provide an example for Europe and other states to follow. ${ }^{89}$

\section{BIBLIOGRAPHY}

1. Buschbacher Connelly, Ulrike. "Disability Rights in Cambodia: Using the Convention on the Rights of People with Disabilities to Expose Human Rights Violations." 18 Pac. Rim L. \& Pol'y J. 123 (January, 2009).

2. Dhanda, Amita. "Legal Capacity in the Disability Rights Convention: Stranglehold of the Past or Lodestar of the Future." 34 Syracuse J. Int'l L. \& Com. 429 (Spring, 2007).

3. Dhir, Aaron. "Human Rights Treat Drafting Through the Lens of Mental Disability: The Proposed International Convention on the Protection and Promotion of the Rights and Dignity of Persons with Disabilities." 41 Stan. J. Int'l L. 181 (Summer, 2005).

4. Kanter, Arlene. "The United Nations Convention on the Rights of Persons with Disabilities and its Implications for the Rights of Elderly People Under International Law." 25 Ga. St. U. L. Rev. 527 (Spring, 2009).

5. Lawson, Anna. "The United Nations Convention on the Rights of Persons with Disabilities: New Era or False Dawn?" 34 Syracuse J. Int'l. L. \& Com. 563 (Spring, 2007).

6. "Lithuania to Preside over EU" // http://lietuva.It/en/state.

7. "Lithuanian Chair of Organization for Security and Cooperation in Europe Sets Out 2011 Priorities as he Briefs Security Council" // http://www.un.org/News/Press/docs/2011/sc10175.doc.htm.

8. Lord, Janet, and Michael Ashely Stein. "The Domestic Incorporation of Human Rights Law and the United Nations Convention on the Rights of Persons with Disabilities." 83 Wash. L. Rev. 449 (November, 2008).

9. Perlin, Michael. "'I Might Need a Good Lawyer, Could be Your Funeral, My Trial': Global Clinical Education and the Right to Counsel in Civil Commitment Cases." 28 Wash. U. J.L. \& Pol'y 241 (2008).

10. Salzman, Leslie. "Rethinking Guardianship (Again): Substituted Decision Making as a Violation of the Integration Mandate of Title II of the Americans with Disabilities Act." 81 U. Colo. L.Rev. 157 (Winter, 2010).

88 See Perlin, supra note 42.

${ }^{89}$ See Lord and Stein, supra note 33: 474 (noting the intangible, but very significant, benefit that states' implementation of the Convention has on changing people's perceptions on the rights of disabled persons). 
11. VŠt "Globali iniciatyva psichiatrijoje". "Neveiksnumo problematika Europos Sajungos deklaruojamu vertybiu kontekste" (The problems of incapacity in the context of European Union declared values) // www.old.gip-vilnius.It/leidiniai/GIP_neveiksnumas.pdf.

12. World Health Organization. "Health topics" // http://www.who.int/topics/disabilities/en/.

13. Žmogaus teisiu stebèjimo institutas. "Žmogaus teisiu igyvendinimas Lietuvoje. Apžvalga" (The implementation of human rights in Lithuania. Review) // http://www.e-library.It/resursai/DB/ZTSI/2003/zt_pr03_15.pdf.

\section{LEGAL REFERENCES}

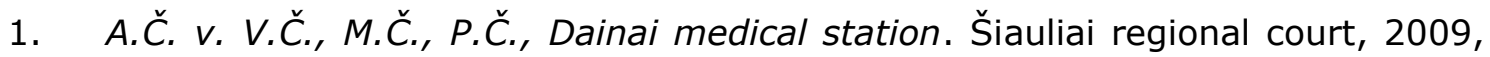
2A-229-45/2009.

2. A.G. v. Marijampole city municipality's administration, Department of social affairs, Social support subdivision. Kaunas regional court, 2009, 2A-102$153 / 2009$.

3. B.L., F.L., R.L. v. Tauragè district municipality's administration, Social support subdivision. Klaipèda regional court, 2008, 2A-302-524/2008.

4. Burghartz v. Switzerland. 31 E.H.R.R. 32 (2001).

5. Civil Code of the Republic of Lithuania. Official Gazette, 2000, no. VIII-1864.

6. Civil Procedure Code of the Republic of Lithuania. Official Gazette, 2002, no. IX-743.

7. Convention and Optional Protocol Signatures and Ratifications [For the Convention on the Rights of Persons with Disabilities, provided by the United Nations "Enable" website] // http://www.un.org/disabilities/countries. asp?navid=17\&pid=166.

8. Convention on the Rights of Persons with Disabilities. G.A. Res. 61/611, U.N. Doc. A/RES/61/611 (Dec.6, 2006).

9. E.Š. v. R.Š., F.Š., H.Š., Širvintos district municipality's administration, Health and Social support subdivision. Vilnius regional court, 2009, 2A-956302/2009.

10. European Convention on Human Rights and Fundamental Freedoms. E.T.S. No. 005 [opened for signature Nov. 4, 1950; entered into force Sept. 3, 1953].

11. Friedl v. Austria. 21 E.H.R.R. 83 (1996).

12. G.A. v. A.S., J.S., R.S., A.S., Utena district municipality's administration, Social support subdivision. Panevėžys regional court, 2010, 2A-8-280/2010. 
13. G.L. v. Vilnius city municipality's administration, Social support subdivision. The Supreme Court of Lithuania, 2007, 3K-3-328/2007.

14. Golder v. The United Kingdom. 1 E.H.R.R. 524 (1979-80).

15. Herczegfalvy v Austria. 15 E.H.R.R. 437 (1993).

16. Law on Mental Health Care of the Republic of Lithuania. Official Gazette, 1995, no. I-924 [as amended on July 5, 2005, no. X-309].

17. Law on Ratification of the UN Convention on the Rights of Persons with Disabilities and its Optional Protocol. Official Gazette, 2010, no. XI-854.

18. Matter v. Slovak Republic. 31 E.H.R.R. 32 (2001).

19. On the compliance of article 3 (wording of 26 June 2001), article 4 (wordings of 26 June 2001 and 3 April 2003), paragraph 3 of article 6 (wording 26 June 2001) and paragraph 1 of article (wording of 26 June 2001) of the Republic of Lithuania law on the restraint of organized crime with the Constitution of the Republic of Lithuania. Ruling of the Constitutional Court of the Republic of Lithuania (December 29, 2004). Official Gazette, 2005, no. 1-7.

20. Recommendation No. R(99) 4 of the Committee of Ministers to Member States on Principles Concerning the Legal Protection of Incapable Adults. Council of Eur. Comm. of Ministers, Principle 6 (1999) //

http://www.coe.int/t/dg3/healthbioethic/texts_and_documents/Rec(99)4E.pdf

21. Shtukaturov v. Russia. 2008 WL 4264284 (European Court of Human Rights, Application no. 44009/05).

22. Summing-Up Note Regarding Decisions Presented by Prosecutors Defending Rights of Social Protected Persons. Prosecution Service of the Republic of Lithuania, 2008, no.13.13-6.

23. T.L. v. Kèdainiai district municipality's administration, Department of culture and education, Social support subdivision. Panevėžys regional court, 2009, 2A-393-544/2009.

24. V.Č., F. ̌. I.M.D. v. Kaunas city municipality's administration, Department of social affairs, Health subdivision. The Supreme Court of Lithuania, 2008, no.3K-3-370/2008.

25. X. v. Croatia. 51 E.H.R.R. 20 (2010).

26. Zehentner v. Austria. 52 E.H.R.R. 22 (2011). 